\title{
Digital Technologies: Development Prospects for Russia
}

\author{
Valentin Kashirin* \\ Department of Economics, Moscow State University, Russian
}

Submission: May 25, 2019; Published: November 06, 2019

*Corresponding author: Valentin Kashirin, Department of Economics, Doctor, Professor, Moscow State University, Russian

Keywords: Digital Technologies; De-Industrialization; Digitalization; System Attack

\section{Opinion}

For the Russian economic practice in modern conditions, the problem of the development of digital technologies is associated with overcoming the de-industrialization of the period of the 1990s and the transformational recession and current crisis trends. Let us turn to the realities of the development of the advanced technology sector today. Modern directions of development generate a system of technologies called "industry 4.0 ". Its peculiarity is "digitalization", i.e. introduction, for example, of sensors capable of transmitting information over the network Internet, etc. from a variety of equipment, etc. For the domestic industry and the economy, it is important not to be late to the stage of implementation of the "industry 4.0".

In terms of the release of Industry 4.0 to the leading position, the following innovations will occur in the organization, technology and process management [1]. In the production can be distinguished two sides, related to the objects of influence "digitalization". This is what is usually referred to as "means of labor" equipment, etc.), as well as "objects of labor" (products for processing, raw materials, etc.).

Some technological devices have inside themselves a kind of module for Internet connection in a wireless version, and it is quite compact. In Industry 4.0., It will be possible to transport apart from one element of an improved conveyor (connected by special sensors via a communication network with other adjacent parts and being in a "constant" dynamics) using such devices. This system provides a high level of flexibility, reliability and sustainability of Industry 4.0."

\section{IT Technologies and Import Substitution}

One more important aspect of the problem should be noted. Recent events related to the introduction of a new phase of "sanctions" make it necessary to revise the criteria for national and economic security. Among these events, special mention should be made of such an event, which is important but not marked as a priority one. We are talking about the so-called "system attack" on Cisco network equipment (routers, servers, etc.) that occurred in early April 2018. As a result, some segments of the Russian Internet (Runet) were partially paralyzed. At the same time, official representatives of the company filed accusations against some anonymous groups of "hackers" from Russia, which sounds, at least, strange. In fact, given the existing features of the CISCO remote access channels, there is more than a clear possibility of influencing the customer's equipment, which the company's representatives themselves consider to be the so-called features of their configuration system. This is a question of economic security on a national scale. Thus, the problem of information security, it should be repeated, is closely related to the problems of economic and national security. There can be no compromise. Therefore, there is a question about import substitution and reproduction of the domestic system, both "hardware" - material support, and "software" - software.

As successful examples are the processors "Baikal-T1" [2]. "The main consumers of Baikal-T1 are manufacturers of telecommunications equipment (routers, IP phones, data storage, etc.), computing equipment, equipment for embedded systems (industrial automation, terminals, automotive systems, etc.)." As for domestic operating systems, the following achievements can be noted here. But, at the beginning, we will highlight the prerequisites for the formation of the domestic "software". The need to develop the domestic software market (software) in the circumstances, for the first time at the highest level, was emphasized in 2014 [3]. There were interesting developments in the field of operating systems.

Such a system (among many - Alt Linux SPT, Platform Alt, OS, etc.) is ROSA. By configuration, it is similar to "Windows", the menu looks functional and simply. Inside there are all the 
necessary "advanced" user "tools. The system boots and turns off pretty quickly. And this is only one domestic operating system. Once again, there is no shortage of domestic operating systems, it's a matter of steps to conquer the market [4]. For the Russian economy this is doubly important in the conditions of overcoming the crisis and the transition to a sustainable hightech type of development.

\section{References}

1. Hacker attack on Cisco equipment led to failures in popular sites of Runet.
2. Almost cyberwar: Attack on the Runet and import substitution.

3. Baikals approached the tests of modern Intel processors. Russia.

4. Andrey Krupin (2017) Made in Russia: a review of 20 Russian operating systems.

5. The operating system DEW - Russian, good (video).
This work is licensed under Creative Commons Attribution 4.0 License DOI: 10.19080/GJAA.2019.10.555800

\section{Your next submission with Juniper Publishers will reach you the below assets}

- Quality Editorial service

- Swift Peer Review

- Reprints availability

- E-prints Service

- Manuscript Podcast for convenient understanding

- Global attainment for your research

- Manuscript accessibility in different formats

( Pdf, E-pub, Full Text, Audio)

- Unceasing customer service

Track the below URL for one-step submission https://juniperpublishers.com/online-submission.php 